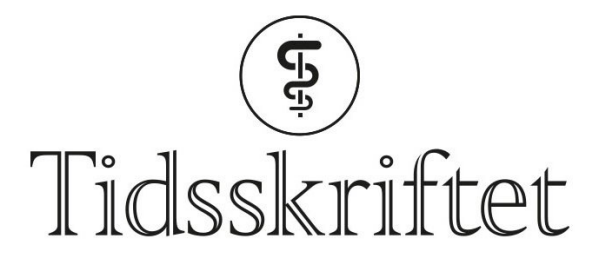

DEN NORSKE LEGEFORENING

\title{
Grundig lærebok om vrangforestillinger
}

ANMELDELSER

SVEIN HAUGSGJERD

Pensjonert psykiater, Oslo

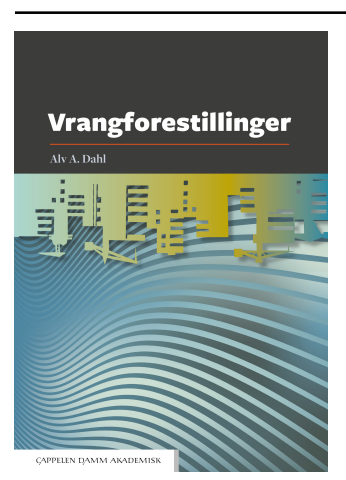

Alv A. Dahl

Vrangforestillinger

285 s, tab, ill. Oslo: Cappelen Damm, 2017. Pris NOK 429

ISBN 978-82-02-53798-2

Alv A. Dahl, tidligere professor i psykiatri, har skrevet en meget grundig lærebok om vrangforestillinger - om begrepets utvikling og vitenskapsfilosofiske bakgrunn, om avgrensning, kartlegging, årsaksforhold og behandling. Det begynner med to korte kasuistikker, den ene svært kjent og omdiskutert i vårt land, nemlig Arnold Juklerød, den andre om den berømte tyske massemorderen Ernst Wagner fra første del av 19oo-tallet.

Når det gjelder diagnostisk klassifikasjon og kriterier, argumenterer Alv A. Dahl overbevisende om at DSM-5 er klarest. Han fremstiller også på en oversiktlig måte den dimensjonale forståelsen av vrangforestillinger. De mest innflytelsesrike psykodynamiske teoriene om vrangforestillinger blir også utførlig diskutert. De to kapitlene om psykoselignende erfaringer i befolkningen byr på nye og viktige kunnskaper om ulike typer og grader av paranoid tenkning.

Kapitlet om årsaksforhold ved utviklingen av vrangforestillinger er meget grundig forskningsmessig belagt og pedagogisk klart fremstilt fra både biologiske, individualpsykologiske og sosiale perspektiver. Forfatteren skiller klart mellom årsaksfaktorer og mellomliggende mekanismer for utvikling av vrangforestillinger, et skille som også den mest erfarne kliniker vil oppleve oppklarende. 
Likedan er kapitlet om behandling godt forskningsmessig forankret, ikke minst når det gjelder medikamentell behandling, og fremstillingen er overbevisende klar rundt psykososiale behandlingsmetoder.

Bokens siste tre kapitler har titlene Religion, ideologi og ekstremisme, 22. juli-terroristen og vrangforestillinger og Kollektive vrangforestillinger. Drøftingen av 22. juli-massemorderen er svært omfattende, og vil nok bli lest med største interesse av veldig mange. Uten å røpe forfatterens egen konklusjon kan det sies at drøftingen av de to sakkyndige komiteenes innstillinger samt rettens begrunnelse er svært nøye ettergått og belyst i relasjon til terroristens egne uttalelser og såkalte manifest. Denne fremstillingen ville nok også kunne påkalle internasjonal oppmerksomhet. I det forutgående og det etterfølgende kapitlet drøfter forfatteren det kompliserte saksområdet, som både historikere og samfunnsvitere vil se som sin hjemmebane, med en kombinasjon av begrepsmessig stringens og nødvendige forbehold om psykiatrifagets avgrensning.

Denne boken bør leses av alle som har behandleransvar i den psykiatriske spesialisthelsetjenesten. Det er grunn til å tro at den også vil bli lest av mange som er opptatt av terrorisme, konspirasjonsteorier og 22. juli-massakren.

Publisert: 12. juni 2018. Tidsskr Nor Legeforen. DOI: 10.4045/tidsskr.18.0154

(C) Tidsskrift for Den norske legeforening 2020. Lastet ned fra tidsskriftet.no 